\title{
Catalytic Inactivation of Human Carbonic Anhydrase I by a Metallopeptide-Sulfonamide Conjugate is Mediated by Oxidation of Active Site Residues
}

Nikhil H. Gokhale, Seth Bradford, and J. A. Cowan*

Evans Laboratory of Chemistry, Ohio State University, 100 West $18^{\text {th }}$ Avenue, Columbus, Ohio 43210

\section{SUPPLEMENTARY INFORMATION}

\section{Materials and Methods}

Both 4-amino benzenesulfonamide, human carbonic anhydrase I (product no. C 4396) and the hydrogenation catalyst ( $\mathrm{Pd} / \mathrm{Charcoal})$ were obtained from Sigma. N-terminally protected tripeptide Z-Gly-Gly-His (where Z is carboxybenzyloxy) was obtained from Bachem. EDC (1ethyl-3-[3-dimethylaminopropyl]carbodiimide hydrochloride) was purchased from Pierce Biotechnology Inc.

\section{Syntheses}

(1) Z-GGHSLN: Fifty mg Z-Gly-Gly-His was dissolved in $0.3 \mathrm{~mL}$ deionized water. To this solution was added $23 \mathrm{mg}$ sulfanilamide in $0.4 \mathrm{~mL}$ methanol. To the resulting methanolic mixture of Z-GGH and sulfanilamide was added $25 \mathrm{mg} \mathrm{EDC.HCl} \mathrm{in} 0.1 \mathrm{~mL}$ water. The solution was stirred overnight and reaction progress was monitored by TLC $\left(\mathrm{EtOAc}: \mathrm{CH}_{3} \mathrm{CN}, 1: 1\right)$. The pure product ZGGHSLN (Yield $30 \mathrm{mg}$ ) was obtained after column chromatography. NMR (DMSO-d6, $250 \mathrm{MHz}) \delta \mathrm{ppm} 7.53(\mathrm{~s}, 1 \mathrm{H}), 7.42(\mathrm{~d}, 3 \mathrm{H}), 7.37(\mathrm{~s}, 5 \mathrm{H}), 7.34(\mathrm{~s}, 2 \mathrm{H}) 6.88(\mathrm{~s}, 3 \mathrm{H})$, $6.69(\mathrm{~s}, 1 \mathrm{H}), 6.57(\mathrm{~d}, 3 \mathrm{H}) 5.80(\mathrm{t}, 3 \mathrm{H}), 5.01(\mathrm{~s}, 2 \mathrm{H}), 3.7(\mathrm{~m}, 2 \mathrm{H}), 3.61$ (s, 1H) MS (ESI) m/e 598 $(\mathrm{M}+\mathrm{K})^{+}$calcd for $\left.\mathrm{C}_{24} \mathrm{H}_{27} \mathrm{~N}_{7} \mathrm{O}_{7} \mathrm{~S}\right)$

(2) GGHSLN: Product Z-GGHSLN was deprotected by hydrogenation. Typically, 30 mg ZGGHSLN was dissolved in 1:1 $\mathrm{CH}_{3} \mathrm{OH}:$ EtOAc and the solution was saturated with hydrogen. To this solution was added $5 \mathrm{mg} \mathrm{Pd}$ on charcoal and the hydrogenation reaction was carried out for $4 \mathrm{~h}$ under a positive pressure of hydrogen. After completion of the reaction (TLC control) the solution was filtered to remove the catalyst and the solvent was evaporated to almost quantitatively yield the deprotected product GGHSLN (yield $28 \mathrm{mg}$ ). NMR (DMSO- $d 6,250$ $\mathrm{MHz}) \delta$ ppm 7.53 (s, 1H), 7.42 (d, 3H), 7.34 (s, 2H) $6.88(\mathrm{~s}, 3 \mathrm{H}) 6.57$ (d, 3H) 5.80 (t, 3H), 5.01 (s, 2H), $3.7(\mathrm{~m}, 2 \mathrm{H}), 3.61(\mathrm{~s}, 1 \mathrm{H}) \mathrm{HRMS}(\mathrm{ESI}) \mathrm{m} / \mathrm{e} 501\left((\mathrm{M}+2 \mathrm{~K})^{+}\right.$calcd for $\left.\mathrm{C}_{16} \mathrm{H}_{21} \mathrm{~N}_{7} \mathrm{O}_{5} \mathrm{~S}\right)$

(3) Cu-GGHSLN: The ligand ZGGHSLN was dissolved in DMSO to obtain a $50 \mathrm{mM}$ stock solution. The copper complex was formed in buffer $(12.5 \mathrm{mM}$ Tris containing $75 \mathrm{mM}$ $\mathrm{NaCl}$ ) as follows. To $22 \mu \mathrm{L}$ of $50 \mathrm{mM}$ DMSO solution containing GGHSLN was added $20 \mu \mathrm{L}$ of $50 \mathrm{mM} \mathrm{CuSO} \mathrm{O}_{4} .5 \mathrm{H}_{2} \mathrm{O}$ solution prepared in water. The addition of $458 \mu \mathrm{L}$ of deionized water followed by addition of $500 \mu \mathrm{L}$ Tris buffer $(25 \mathrm{mM}, 150 \mathrm{mM} \mathrm{NaCl}, \mathrm{pH} 8.0)$ resulted in a $1 \mathrm{mM}$ Cu-GGHSLN complex stock solution with metal to ligand ratio as 1:1.1. The $\mathrm{Cu}^{2+}$ complex of GGHSLN demonstrated the characteristic absorbance signature for GGH-bound $\mathrm{Cu}^{2+}\left(\lambda_{\max }=\right.$ $525 \mathrm{~nm}$ ) as well as a $\mathrm{Cu}^{3+/ 2+}$ redox couple of $1.23 \mathrm{~V}$ (vs NHE). 


\section{Human Carbonic Anhydrase I (CA-I) Activity Assay}

Human CA-I activity was measured by its esterase activity with 4-nitrophenyl acetate as substrate. Typically the enzyme activity was measured at $400 \mathrm{~nm}$ in a continuous spectrophotometric assay (final volume of $0.3 \mathrm{~mL}$ containing $10 \mu \mathrm{g}$ CA-I and $1 \mathrm{mM}$ substrate, with a final buffer composition of $12.5 \mathrm{mM}$ Tris, $75 \mathrm{mM} \mathrm{NaCl}, \mathrm{pH} 8.0$ ). The increase in absorbance at $400 \mathrm{~nm}$ was monitored over $2 \mathrm{~min}$ at intervals of $4 \mathrm{sec}$. The substrate was dissolved in DMSO and an aliquot of the stock solution was added to initiate the enzymatic reaction. The presence of DMSO up to $5 \%$ in the assay volume did not affect the enzyme activity.

\section{Human Carbonic Anhydrase I (CA-I) Inhibition Assay}

Inhibition of human CA-I in the presence and absence of inhibitors (inhibitors tested include: 4-carboxybenzene sulfonamide, sulfanilamide, GGHSLN and Cu-GGHSLN) was evaluated by use of the enzyme assay described above. Dose-dependent inhibition of the CA-I activity was measured by incubating $0-80 \mu \mathrm{M}$ inhibitor with the enzyme for 5 min prior to initiating the reaction by addition of substrate. The initial velocities obtained in the presence or absence of inhibitors was converted to percent activity with respect to the control reaction containing no inhibitor. The $\%$ activity data was plotted as the function of inhibitor concentration and fitted to the dose response curve to obtain $\mathrm{IC}_{50}$ values. Based on the $\mathrm{K}_{\mathrm{M}}$ value for substrate $(3.88 \mathrm{mM})$ the $\mathrm{K}_{\mathrm{I}}$ values were calculated by use of the equation $\mathrm{K}_{\mathrm{I}}=\mathrm{IC}_{50} /\left(1+[\mathrm{S}] / \mathrm{K}_{\mathrm{M}}\right)$.

\section{Reaction conditions used to obtain samples for MS (Q-TOF2 electrospray) analyses}

Reactions were performed at room temperature and consisted of $100 \mu \mathrm{L}$ solutions containing $20 \mu \mathrm{M}$ CA-I, $2 \mathrm{mM}$ L-ascorbic acid and $10 \mu \mathrm{M}$ Cu-GGHSLN in Tris buffer $(12.5$ $\mathrm{mM}, 75 \mathrm{mM} \mathrm{NaCl}, \mathrm{pH}=8.0$ ). The reaction mixture was incubated for $3 \mathrm{~h}$ prior to quenching by addition of EDTA (final concentration $1.5 \mathrm{mM}$ ). Control reactions containing only ascorbate, and in the presence of $\mathrm{Cu}^{2+}(\mathrm{aq})$ were also run simultaneously (Figures SI5 to 7).

All experiments were performed on a Micromass Q-Tof ${ }^{\mathrm{TM}}$ II (Micromass, Wythenshawe, UK) mass spectrometer equipped with an orthogonal nanospray source (Z-spray) operated in positive ion mode. MS/MS of Glu-fibrino peptide was used for mass calibration for a calibration range of $\mathrm{m} / \mathrm{z} 100-2000$. Samples were prepared in a solution containing acetonitrile and formic acid and infused into the nanospray source at a rate of $0.5-1 \mu 1 \mathrm{~min}^{-1}$. Optimal conditions were: capillary voltage $3000 \mathrm{~V}$, source temperature $110^{\circ} \mathrm{C}$ and a cone voltage of $60 \mathrm{~V}$. Q1 was set to optimally pass ions from m/z $100-2000$ and all ions transmitted into the pusher region of the TOF analyzer were scanned with a $1 \mathrm{~s}$ integration time. Data was acquired in continuum mode until acceptable averaged data was obtained. Maxent was used to deconvolute the raw ESI charge state data to calculate the average mass of the protein.

\section{Reaction conditions used to obtain samples for LC MS/MS analyses}

Reactions were performed at room temperature and consisted of $100 \mu \mathrm{L}$ solutions containing $20 \mu \mathrm{M}$ CA-I, $2 \mathrm{mM}$ L-ascorbic acid and $10 \mu \mathrm{M}$ Cu-GGHSLN in Tris buffer $(12.5$ $\mathrm{mM}, 75 \mathrm{mM} \mathrm{NaCl}, \mathrm{pH}=8.0$ ). The reaction mixture was incubated for 3 hours prior to quenching by addition of EDTA (final concentration $1.5 \mathrm{mM}$ ). Control reactions containing only ascorbate, and in the presence of $\mathrm{Cu}^{2+}(\mathrm{aq})$ were also run simultaneously. Upon quenching of the reactions, the samples were desalted. 
Intact protein was digested using a protocol similar to that reported by Russell et al., [Anal. Chem. 73, 2682-85, 2001]. Proteins were desalted using manual syringe protein traps from Michrom BioResources (Auburn, CA) and re-suspended in $10 \mu \mathrm{L}$ of water. $5 \mu \mathrm{L}$ of a 5 $\mathrm{mg} / \mathrm{mL}$ of DTT in $100 \mathrm{mM}$ ammonium bicarbonate was added to reduce the cysteines. Sequencing grade trypsin from Promega (Madison WI) was prepared as $80 \mathrm{ng} / \mu \mathrm{L}$ in $50 \mathrm{mM}$ acetic acid. The final buffer conditions for digestion were $25 \mathrm{mM}$ ammonium bicarbonate and $40 \%$ acetonitrile. The digestion was carried out at room temperature for $4 \mathrm{~h}$ and stopped by acidification.

Capillary-liquid chromatography-nanospray tandem mass spectrometry (NanoLC/MS/MS) was performed on a Thermo Finnigan LTQ mass spectrometer equipped with a nanospray source operated in positive ion mode. The LC system was a UltiMate ${ }^{\mathrm{TM}}$ Plus system from LC-Packings A Dionex Co (Sunnyvale, CA) with a Famous autosampler and Switchos column switcher. The solvent A was water containing $50 \mathrm{mM}$ acetic acid and the solvent $\mathrm{B}$ was acetonitrile. Five microliters of each sample was first injected on to the trapping column (LCPackings A Dionex Co, Sunnyvale,CA), and washed with $50 \mathrm{mM}$ acetic acid. The injector port was switched to inject and the peptides were eluted off of the trap onto the column. A $5 \mathrm{~cm} 75$ $\mu \mathrm{m}$ ID ProteoPep II C18 column (New Objective, Inc. Woburn, MA) packed directly in the nanospray tip was used for chromatographic separations. Peptides were eluted directly off the column into the LTQ system using a gradient of $2-80 \%$ B over 30 minutes, with a flow rate of $300 \mathrm{nl} / \mathrm{min}$. A total run time was 58 minutes. The scan sequence of the mass spectrometer was programmed for a full scan, a zoom scan to determine the charge of the peptide and a MS/MS scan of the most abundant peak in the spectrum. Dynamic exclusion was used to exclude multiple MS/MS of the same peptide.

Sequence information from the MS/MS data was processed using Mascot Distiller to form a peaklist and by using MASCOT MS/MS search engine and Turbo SEQUEST algorithm in BioWorks 3.1 Software. Data processing was performed following the guidelines in Molec. Cell. Proteomics. Assigned peaks have a minimum of 10 counts ( $\mathrm{S} / \mathrm{N}$ of 3 ). The mass accuracy of the precursor ions was set to $1.5 \mathrm{Da}$ to accommodate accidental selection of the $\mathrm{C} 13$ ion and the fragment mass accuracy was set to $0.5 \mathrm{Da}$. 


\section{FIGURES FOR SUPPLEMENTARY INFORMATION}

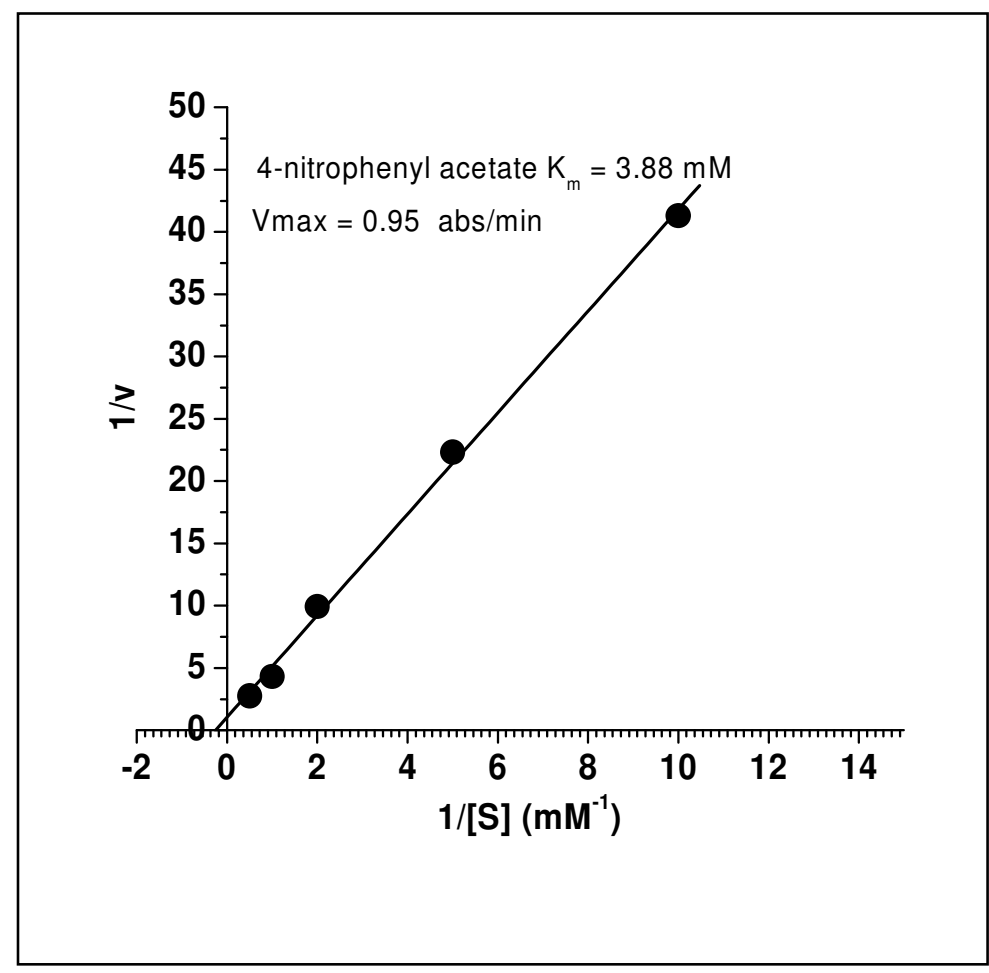

Figure SI1. Determination of $\mathbf{K}_{M}$ for 4-nitrophenyl acetate. The $\mathrm{K}_{M}$ for CA-I promoted hydrolysis of 4nitrophenyl acetate was measured by incubating a fixed concentration of the enzyme with variable concentration of the substrate and determining the enzyme activity as detailed in the experimental methods presented earlier. A plot of reciprocal of initial velocity versus the reciprocal substrate concentration yielded the $K_{M}$ value as the reciprocal negative intercept. The value was determined to be 3.88 $\mathrm{mM}$. 
Figure SI2. Dose dependence response curves. The left panel shows the enzyme activity data obtained by measuring the increase in absorbance at $400 \mathrm{~nm}$ resulting from the esterase activity of CA-I with 4-nitrophenyl acetate in the presence of various concentrations $(0-80 \mu \mathrm{M})$ of inhibitors. The data was fit to obtain the initial velocity, that in turn was converted to the \% CAI activity with respect to the control and fit to a dose-response function to obtain $\mathrm{IC}_{50}$ values (right panel) using the equation $\mathrm{K}_{\mathrm{I}}=\mathrm{IC}_{50} /\left(1+[\mathrm{S}] / \mathrm{K}_{\mathrm{M}}\right)$. The rate of hydrolysis of substrate only, in the absence of enzyme, was subtracted from each data set.

Inhibition by 4-carboxy benzene sulfonamide : $\mathbf{I C}_{\mathbf{5 0}}=\mathbf{0 . 9} \mu \mathrm{M}$

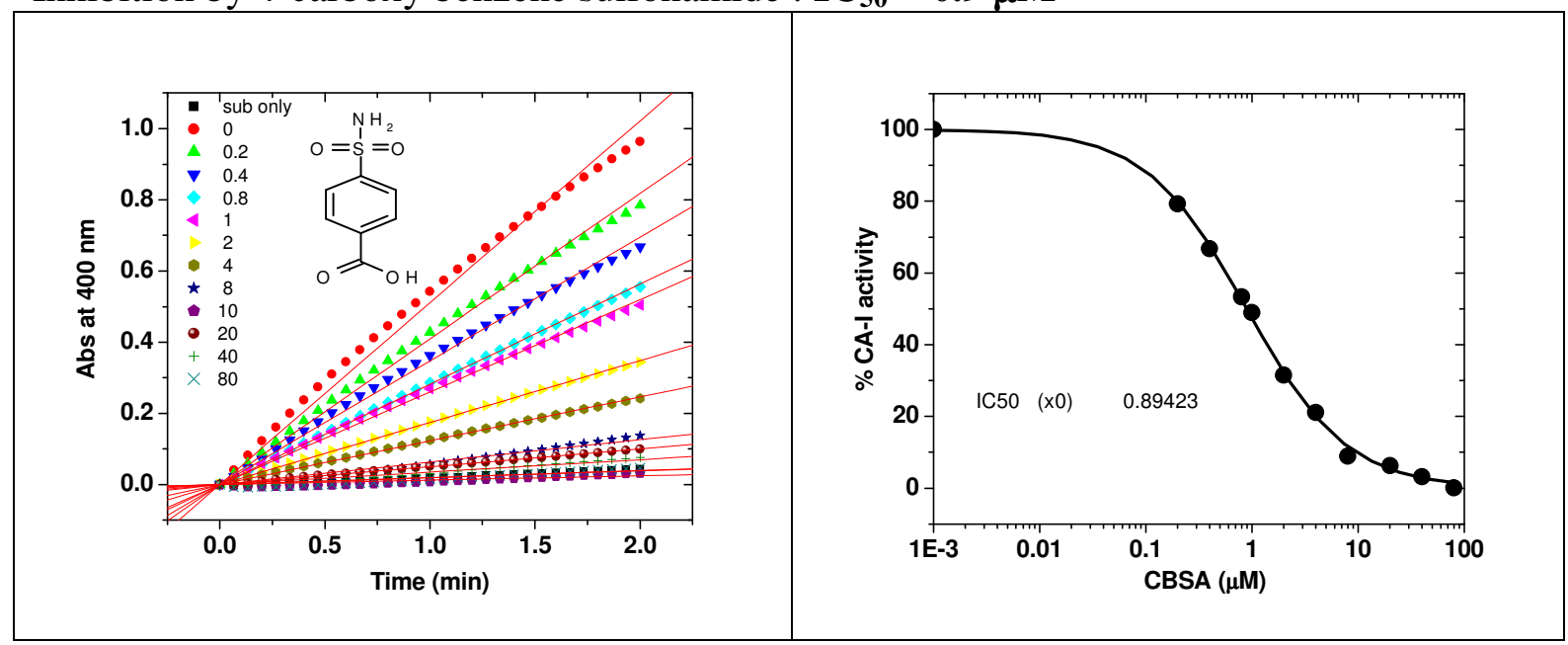

Inhibition by sulfanilamide: $\mathrm{IC}_{\mathbf{5 0}}=\mathbf{1 0 . 3} \boldsymbol{\mu M}$

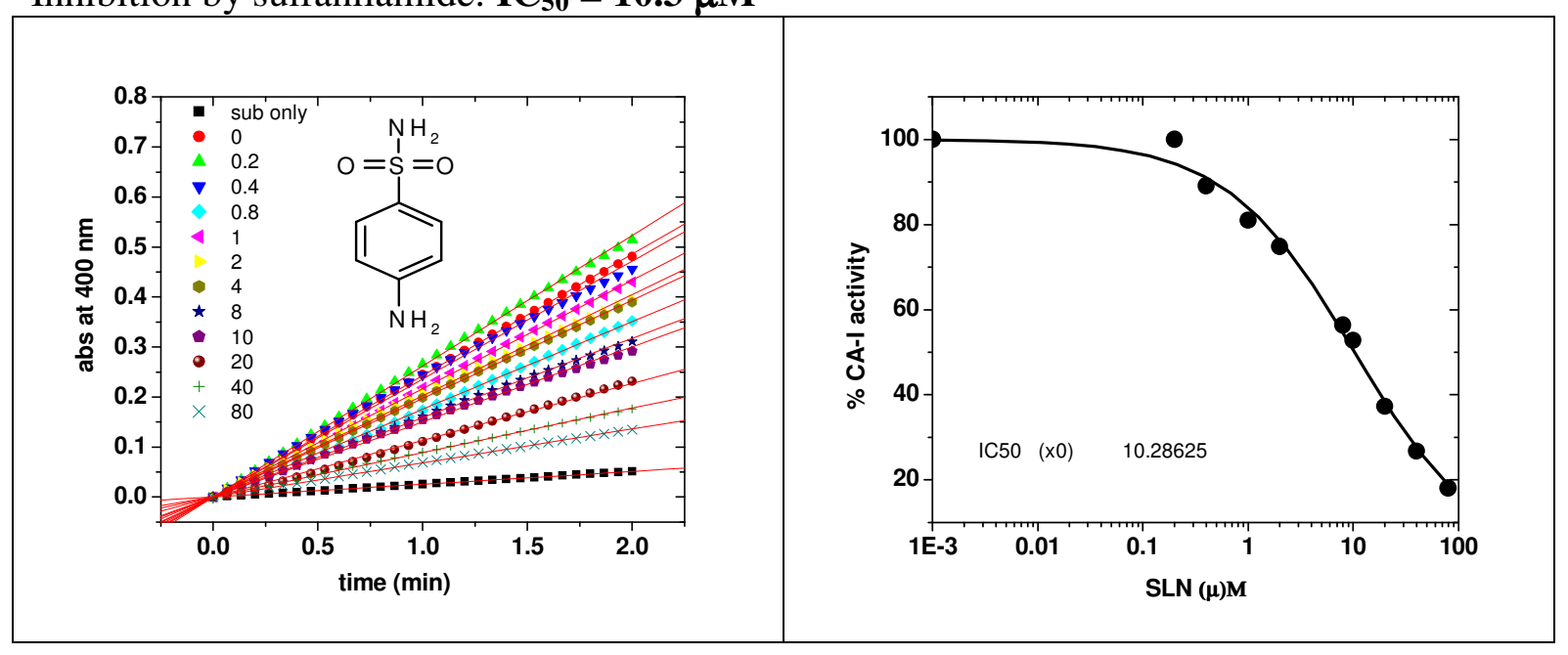


Inhibition by the GGHSLN conjugate: : $\mathbf{I C}_{\mathbf{5 0}}=\mathbf{6 . 5 0} \mu \mathbf{M}$

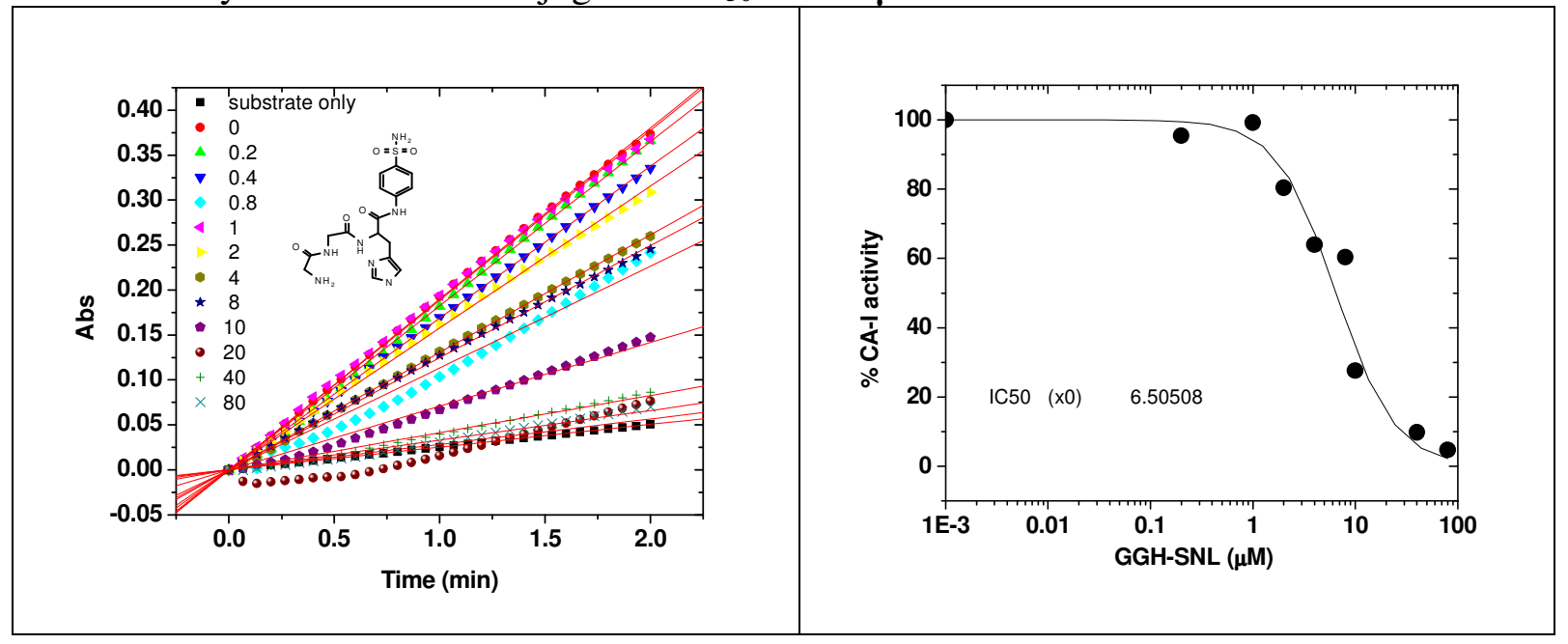

Inhibition by the [Cu-GGHSLN] complex: : $\mathbf{I C}_{50}=\mathbf{6 . 3 0} \mu \mathbf{M}$

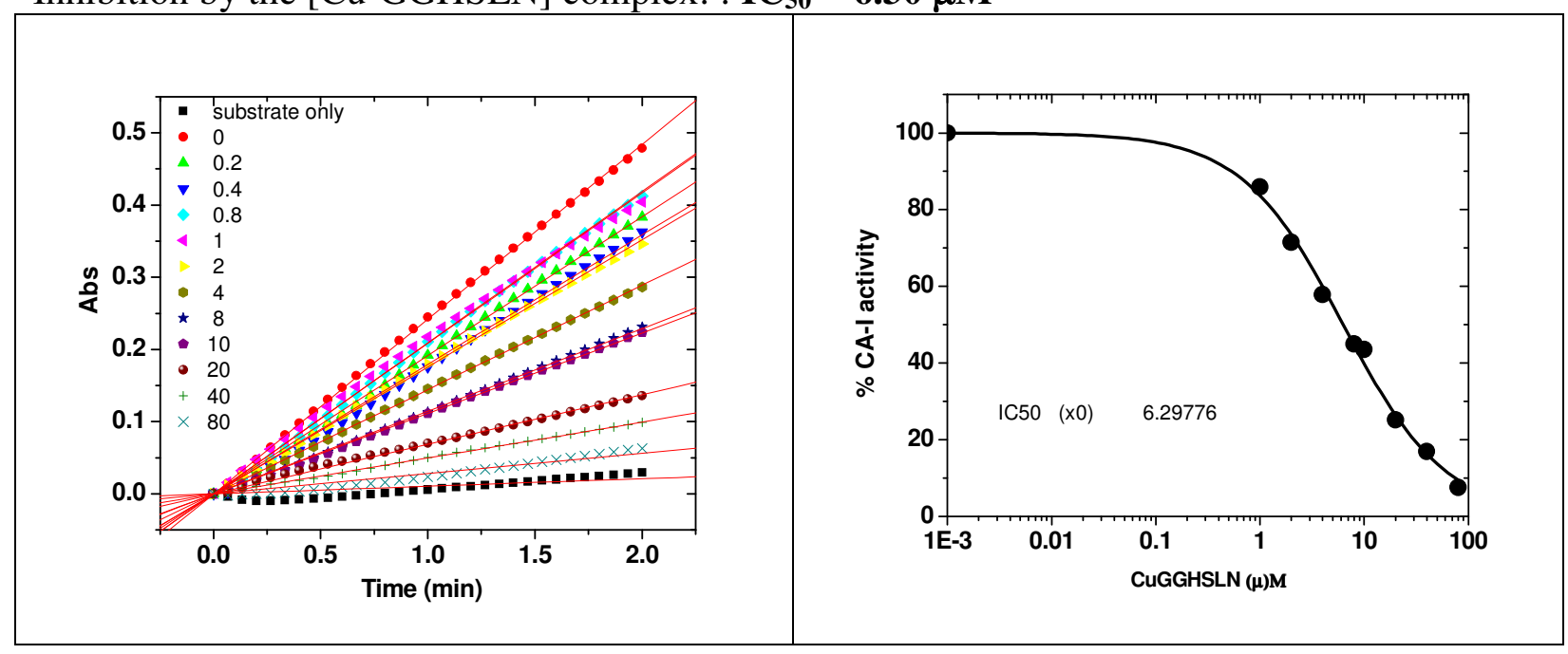


Figure SI3. UV-VIS and electrochemical characteristics of Cu-GGHSLN relative to the metal-free ligands.

\begin{tabular}{|l|l|}
\hline \\
0.18 \\
$0.14-1$
\end{tabular}


Figure SI4. SDS-PAGE (12\%) analysis of oxidative damage to human Carbonic Anhydrase I mediated by $\mathrm{Cu}^{2+}(\mathrm{aq})$ and the copper peptides shown. Reactions were incubated with free copper and copper-peptide complexes with ascorbate for $60 \mathrm{~min}$ at room temperature prior to gel electrophoresis. No cleavage products were detected.

$\begin{array}{llll}3 & 2 & 1 & \mathrm{M}\end{array}$

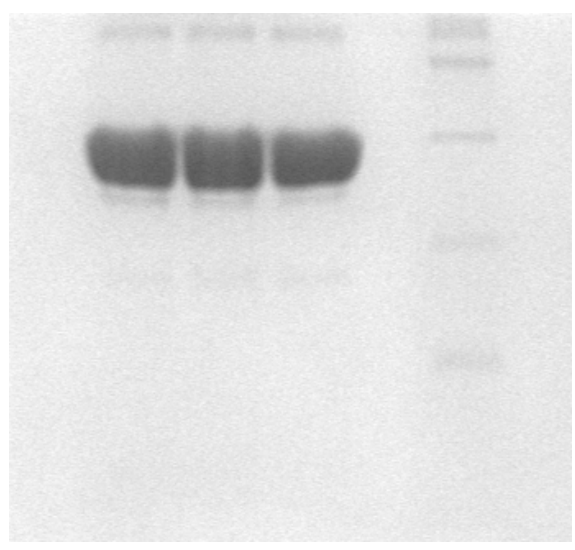

$1=100 \mu \mathrm{M}$ CA-I $+100 \mu \mathrm{M} \mathrm{Cu}^{2+}(\mathrm{aq})+1 \mathrm{mM}$ Ascorbate

$2=100 \mu \mathrm{M}$ CA-I $+100 \mu \mathrm{M} \mathrm{Cu}($ GGHSLN $)+1 \mathrm{mM}$ Ascorbate

$3=100 \mu \mathrm{M} \mathrm{CA}-\mathrm{I}+100 \mu \mathrm{M} \mathrm{Cu}(\mathrm{KGHKSLN})+1 \mathrm{mM}$ Ascorbate

$\mathrm{M}=$ molecular weight marker 
Figure SI5. Showing the mass peak for the Human Carbonic Anhydrase I obtained from the deconvoluted ESI data . Reactions were performed at room temperature and consisted of $100 \mu \mathrm{L}$ solutions containing $20 \mu \mathrm{M}$ CA-I and $2 \mathrm{mM}$ L-ascorbic acid in Tris buffer $(12.5 \mathrm{mM}, 75 \mathrm{mM}$ $\mathrm{NaCl}, \mathrm{pH}=8.0$ ). The reaction mixtures were incubated for $3 \mathrm{~h}$ prior to quenching by addition of EDTA (final concentration $1.5 \mathrm{mM}$ ) and MS analyses.

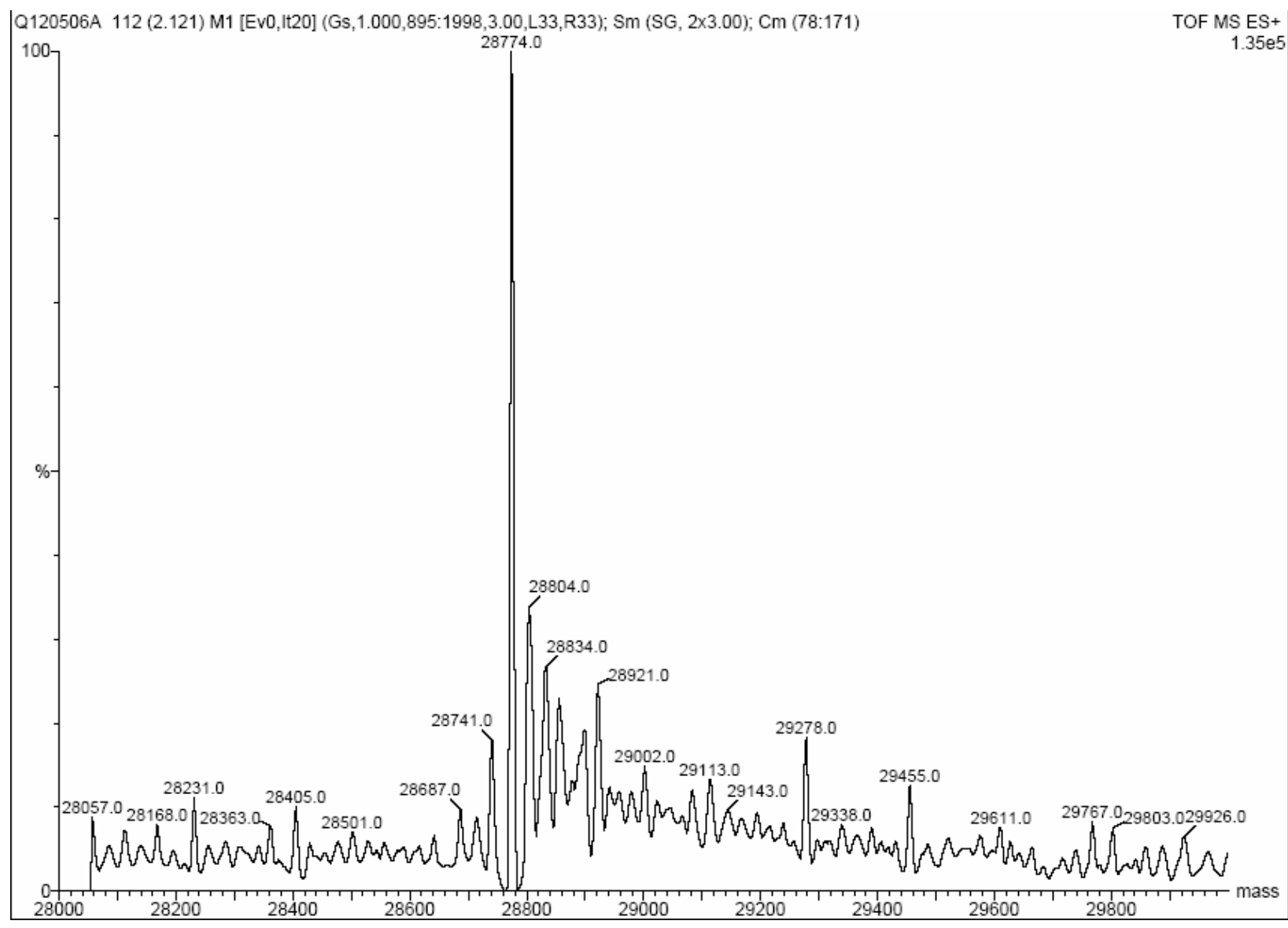

The mass peak at 28774 is consistent with intact protein, with no oxidation of the amino acid residues in the presence of L-ascorbic acid. 
Figure SI6. Showing the mass peak for the Human Carbonic Anhydrase I obtained from the deconvoluted ESI data . Reactions were performed at room temperature and consisted of $100 \mu \mathrm{L}$ solutions containing $20 \mu \mathrm{M}$ CA-I, $2 \mathrm{mM}$ L-ascorbic acid and $10 \mu \mathrm{M} \mathrm{Cu}^{2+}(\mathrm{aq})$ in Tris buffer $(12.5 \mathrm{mM}, 75 \mathrm{mM} \mathrm{NaCl}, \mathrm{pH}=8.0)$. The reaction mixtures were incubated for $3 \mathrm{~h}$ prior to quenching by addition of EDTA (final concentration $1.5 \mathrm{mM}$ ) and MS analyses.

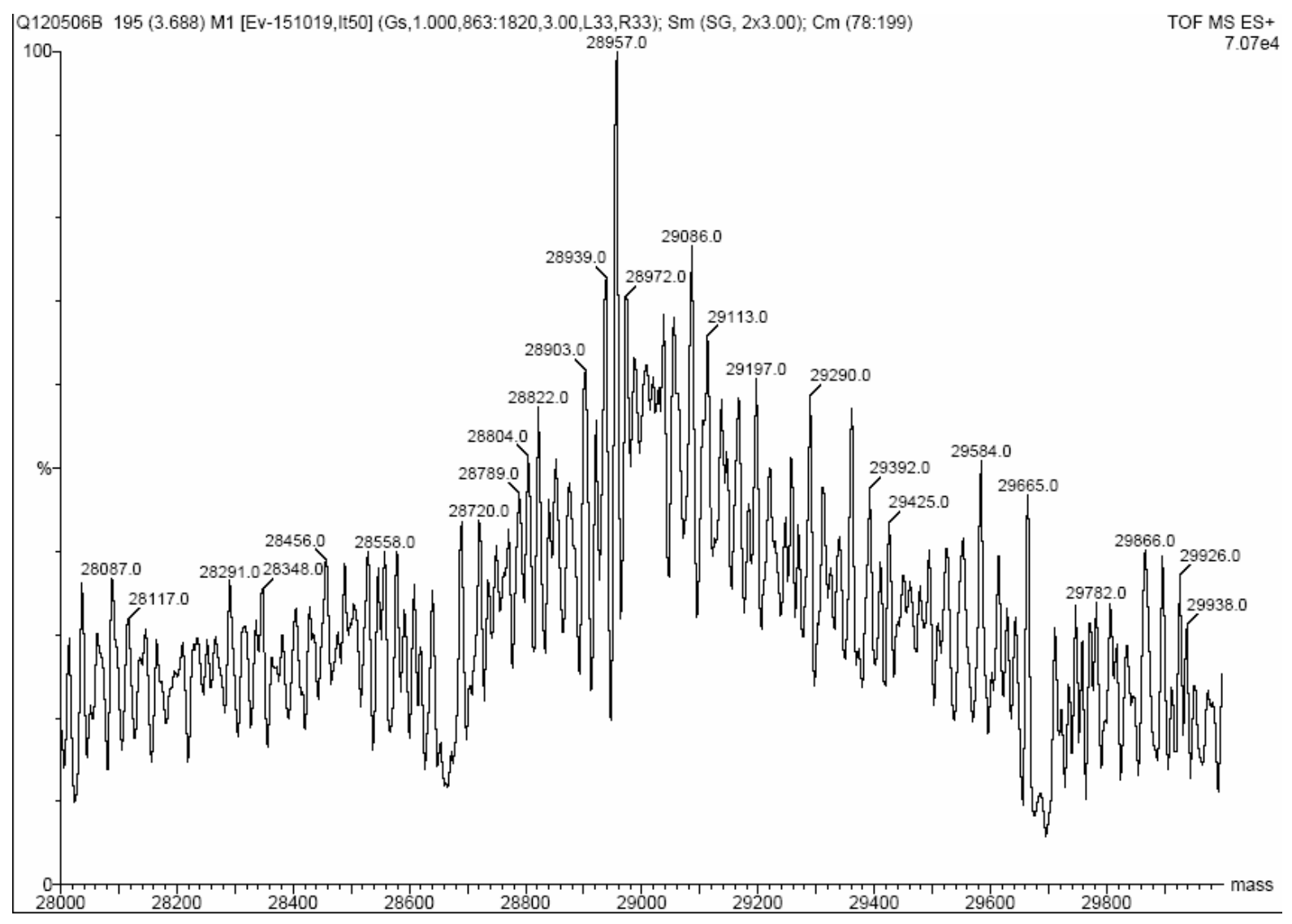

The mass peak at 28957 is consistent with protein oxidation in the presence of L-ascorbic acid and $\mathrm{Cu}^{2+}(\mathrm{aq})$. 
Figure SI7. Showing the mass peak for the Human Carbonic Anhydrase I obtained from the deconvoluted ESI data . Reactions were performed at room temperature and consisted of $100 \mu \mathrm{L}$ solutions containing $20 \mu \mathrm{M}$ CA-I, $2 \mathrm{mM}$ L-ascorbic acid and $10 \mu \mathrm{M}$ Cu-GGHSLN in Tris buffer $(12.5 \mathrm{mM}, 75 \mathrm{mM} \mathrm{NaCl}, \mathrm{pH}=8.0)$. The reaction mixtures were incubated for $3 \mathrm{~h}$ prior to quenching by addition of EDTA (final concentration $1.5 \mathrm{mM}$ ) and MS analyses.

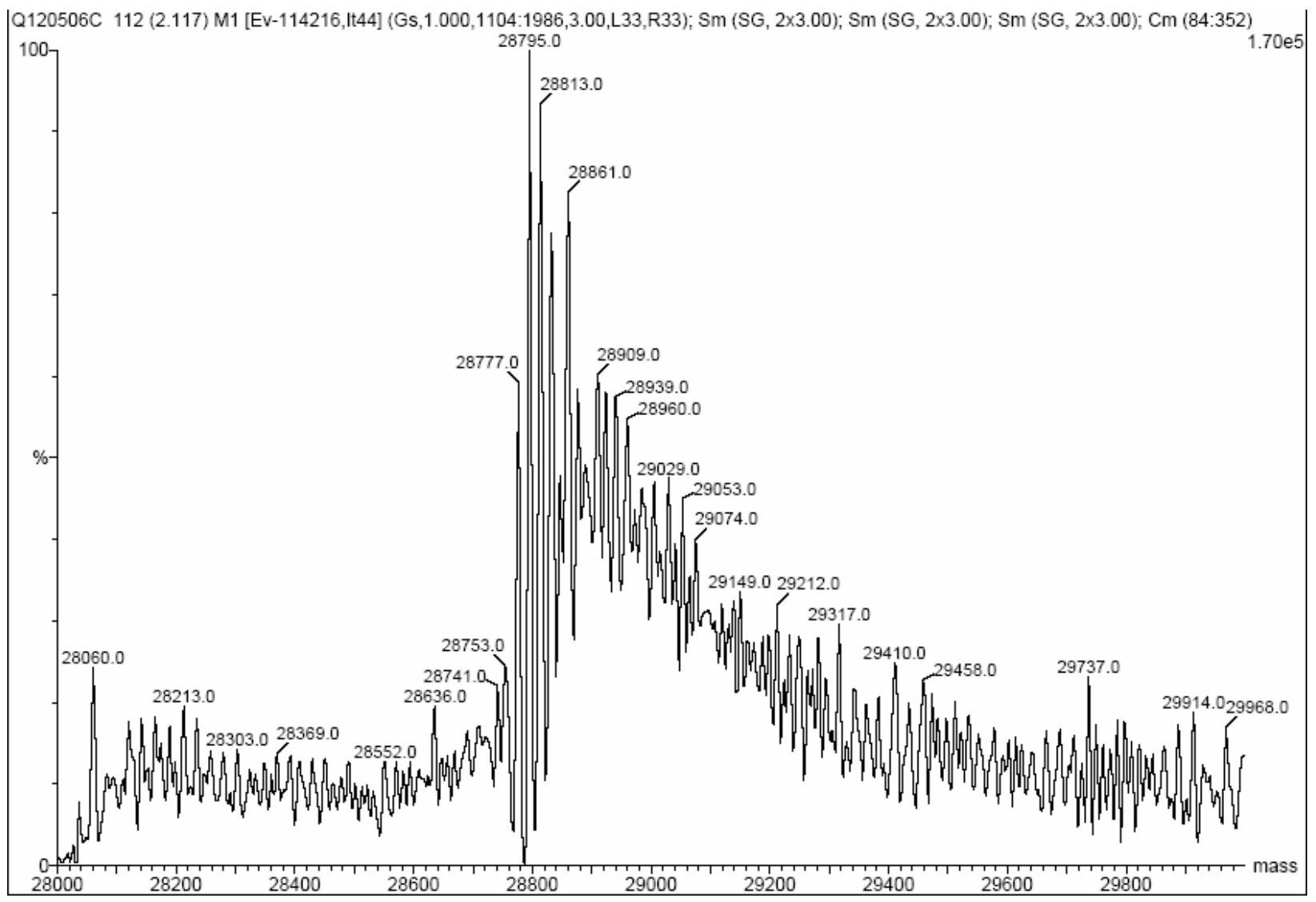

The mass peak at 28795 is consistent with protein oxidation in the presence of L-ascorbic acid and $\mathrm{Cu}-\mathrm{GGHSLN}$. 
Figure SI8. Human Carbonic Anhydrase-I sequence showing chymotrypsin cleavage sites ( I), the active site Zinc binding histidine residues (underlined), and oxidized residues upon interaction with $\mathrm{Cu}-\mathrm{GGHSLN}$ and L-ascorbic acid (doubly underlined). The protein $(20 \mu \mathrm{M})$ was incubated with $\mathrm{Cu}-\mathrm{GGHSLN}(10 \mu \mathrm{M})$ and L-ascorbic acid $(2 \mathrm{mM})$ under aerobic conditions in Tris buffer (12.5 mM, $75 \mathrm{mM} \mathrm{NaCl}, \mathrm{pH}$ 7.6) for three hours prior to digestion with chymotrypsin under non-reducing conditions. Nano LC/MS/MS was performed in order to obtain sequence information, $90 \%$ of the protein sequence was covered and the residues not included in sequence information are grayed.

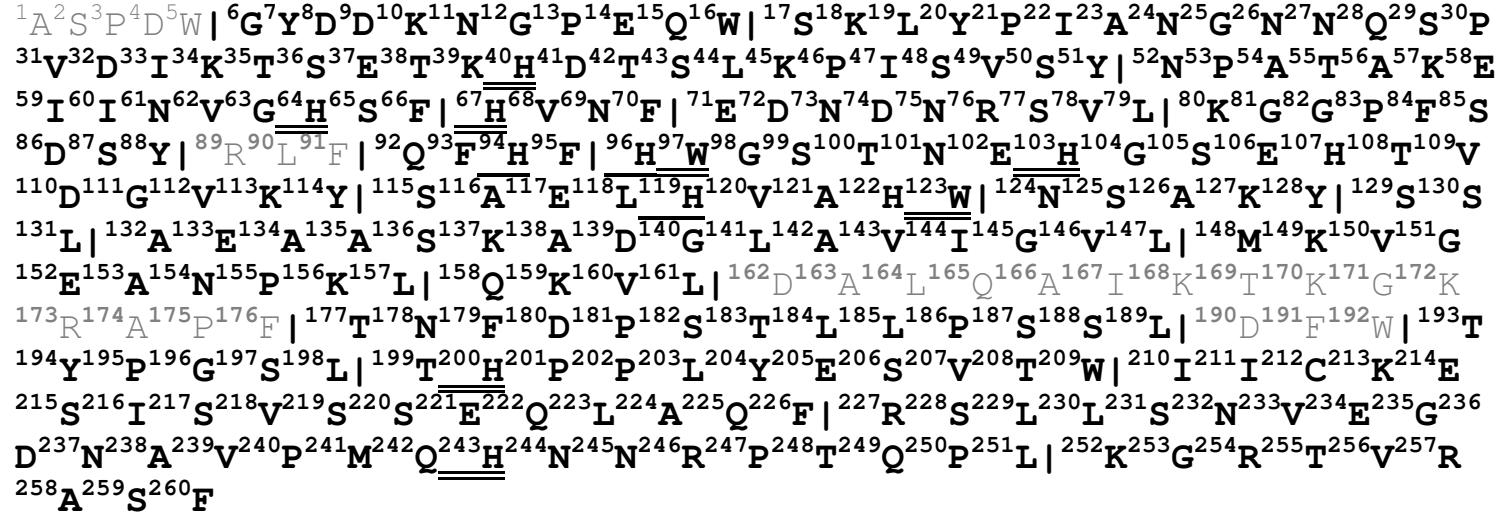


Figure SI9. Control experiments for time-dependent inactivation of CA-I mediated by $\mathbf{C u}^{2+}(\mathbf{a q})$. Human carbonic anhydrase I (CA-I) activity was measured at the specified time intervals. The reactivity of copper ion under oxidative conditions was examined through a series of reactions $(0.3 \mathrm{~mL}$ final volume) containing $1.1 \mu \mathrm{M}$ CA-I, with zero time started at the simultaneous incubation of all reactions with $\mathrm{Cu}^{2+}(\mathrm{aq})(5 \mu \mathrm{M})$ and ascorbate $(1 \mathrm{mM})$ in Tris buffer $(12.5 \mathrm{mM}, 75 \mathrm{mM} \mathrm{NaCl}, \mathrm{pH} 8.0)$. The activity at each time interval was determined under initial velocity conditions with $1 \mathrm{mM}$ substrate (4-nitrophenyl acetate). Control reactions

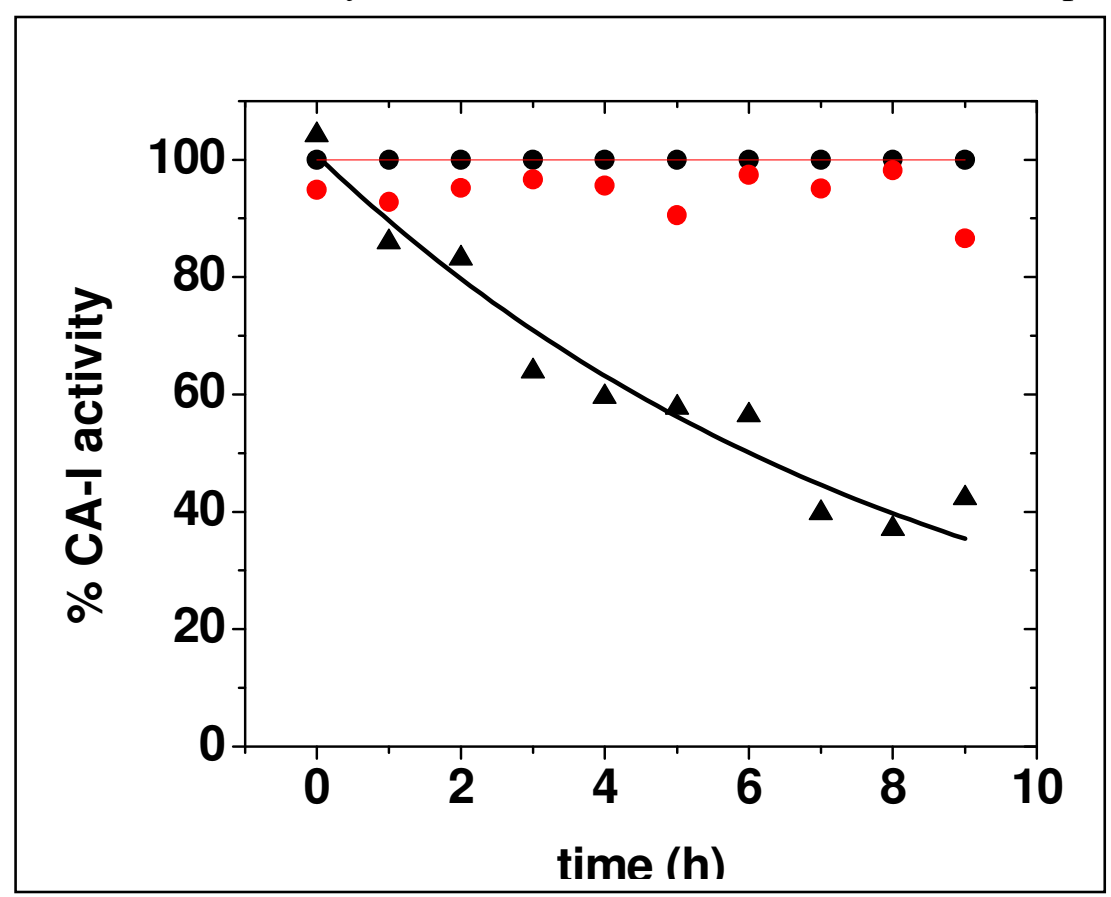
with and without $\mathrm{Cu}^{2+}(\mathrm{aq})$ and no ascorbate were run simultaneously. The initial velocity data was converted to \% CA-I activity with respect to control and plotted as a function of time. The figure shows a control reaction lacking added copper ion (•), a "hydrolytic" reaction in the presence of copper but the absence of ascorbate $(\bullet)$, and a reaction including copper ion and ascorbate ( $\mathbf{\Delta})$. The fitted $\mathrm{k}_{\mathrm{obs}}$ for oxidative inactivation by $\mathrm{Cu}^{2+}(\mathrm{aq})$ is $\sim 0.003 \mathrm{~min}^{-1}$. 
Table SI1. Observed and calculated mass for the proteolytic fragments of oxidized human Carbonic Anhydrase-I upon treatment with chymotrypsin (90\% protein sequence covered). The protein was preincubated with Cu-GGHSLN inhibitor and L-ascorbic acid for $3 \mathrm{~h}$ prior to proteolytic digestion.

\begin{tabular}{|l|l|l|l|l|l|l|l|}
\hline Fragment & $\operatorname{Mr}(\mathrm{obs})$ & $\mathrm{Mr}(\mathrm{calc})$ & $\begin{array}{l}\text { Residue } \\
\text { Oxidized }\end{array}$ & Fragment & $\operatorname{Mr}(\mathrm{obs})$ & $\mathrm{Mr}(\mathrm{calc})$ & $\begin{array}{l}\text { Residue } \\
\text { Oxidized }\end{array}$ \\
\hline$[6-16]^{2+}$ & 1308.8234 & 1307.5418 & & {$[115-123]^{2+}$} & 1065.4434 & 1064.5039 & $\mathrm{~W} 123$ \\
\hline$[17-51]^{3+}$ & 3831.1842 & 3830.9690 & & {$[129-147]^{2+}$} & 1769.9734 & 1770.9726 & \\
\hline$[17-51]^{3+}$ & 3848.5842 & 3846.9639 & $\mathrm{H} 40$ & {$[129-157]^{3+}$} & 2854.7542 & 2854.5473 & \\
\hline$[52-66]^{2+}$ & 1596.5934 & 1596.8259 & & {$[132-147]^{2+}$} & 1484.2134 & 1483.8245 & \\
\hline$[52-66]^{2+}$ & 1612.7234 & 1612.8209 & $\mathrm{H} 64$ & {$[148-161]^{3+}$} & 1554.9834 & 1553.8963 & \\
\hline$[52-70]^{2+}$ & 2092.1034 & 2094.0646 & & {$[148-161]^{3+}$} & 1570.5842 & 1569.8912 & \\
\hline$[52-79]^{3+}$ & 3136.2242 & 3136.5325 & & {$[177-189] 1^{+}$} & 1390.5927 & 1390.6980 & \\
\hline$[52-79]^{3+}$ & 3153.3442 & 3152.5274 & $\mathrm{H} 67$ & {$[193-198] 1^{+}$} & 636.4127 & 636.3119 & \\
\hline$[67-79]^{2+}$ & 1556.8134 & 1557.7171 & & {$[193-209] 2^{+}$} & 1946.9334 & 1946.9414 & \\
\hline$[67-79]^{2+}$ & 1572.3434 & 1573.7121 & $\mathrm{H} 67$ & {$[193-209] 2^{+}$} & 1964.0934 & 1962.9363 & $\mathrm{H} 200$ \\
\hline$[80-88]^{2+}$ & 956.4827 & 956.4239 & & {$[210-226] 2^{+}$} & 1881.2134 & 1880.9553 & \\
\hline$[92-114]^{3+}$ & 2698.9742 & 2698.1948 & & {$[227-251] 3^{+}$} & 2801.5742 & 2802.3831 & $\mathrm{H} 243$ \\
\hline$[92-114]^{3+}$ & 2716.0742 & 2714.1898 & $\mathrm{H} 103$ & {$[227-251] 3^{+}$} & 2804.2742 & 2802.3831 & \\
\hline$[96-114]^{3+}$ & 2155.9942 & 2154.9355 & $\mathrm{~W} 97$ & {$[231-251] 3^{+}$} & 2332.4742 & 2333.0818 & $\mathrm{H} 243$ \\
\hline$[115-123]^{2+}$ & 1048.4727 & 1048.5090 & & {$[252-260] 2^{+}$} & 1020.1934 & 1020.5828 & \\
\hline
\end{tabular}


Table SI2. Observed and calculated mass for the proteolytic fragments of oxidized human Carbonic Anhydrase-I upon treatment with trypsin (60\% protein sequence covered). The protein was preincubated with $\mathrm{Cu}-\mathrm{GGHSLN}$ inhibitor and L-ascorbic acid for $3 \mathrm{~h}$ prior to proteolytic digestion.

\begin{tabular}{|l|l|l|l|l|l|l|l|}
\hline Fragment & Mr(obs) & Mr(calc) & $\begin{array}{l}\text { Residue } \\
\text { Oxidized }\end{array}$ & Fragment & Mr(obs) & Mr(calc) & $\begin{array}{l}\text { Residue } \\
\text { Oxidized }\end{array}$ \\
\hline$[19-34]^{2+}$ & 1741.6134 & 1741.8998 & & {$[150-159]^{2+}$} & 1083.1134 & 1082.6084 & \\
\hline$[19-39]^{3+}$ & 2288.2542 & 2288.1648 & & {$[150-168]^{2+}$} & 2034.8434 & 2034.1836 & \\
\hline$[35-57]^{3+}$ & 2474.6934 & 2474.2652 & & {$[157-170]^{3+}$} & 1568.1042 & 1567.9661 & \\
\hline$[35-57]^{3+}$ & 2491.3142 & 2490.2602 & H40 & {$[160-168]^{1+}$} & 969.6127 & 969.5858 & \\
\hline$[58-80]^{3+}$ & 2683.2042 & 2682.3149 & & {$[160-170]^{2+}$} & 1197.3034 & 1198.7285 & \\
\hline$[81-89]^{1+}$ & 984.4427 & 984.4301 & & {$[160-172]^{2+}$} & 1384.1334 & 1383.8449 & \\
\hline$[128-137]^{1+}$ & 1025.4527 & 1025.5029 & & {$[214-227]^{2+}$} & 1581.6634 & 1579.7841 & \\
\hline$[128-149]^{3+}$ & 2193.2242 & 2193.1714 & & {$[228-254]^{3+}$} & 3005.2542 & 3003.4944 & H243 \\
\hline$[138-149]^{2+}$ & 1185.0834 & 1185.6791 & & & & & \\
\hline
\end{tabular}


Table SI3. Comparison of inhibition constants $\left(\mathrm{K}_{\mathrm{I}}\right)$ of known CA-I inhibitors relative to the bifunctional ligand and its copper chelate.

\begin{tabular}{|l|l|l|}
\hline Inhibitor & $\mathrm{IC}_{50}(\mu \mathrm{M})$ & $\mathrm{K}_{\mathrm{I}}(\mu \mathrm{M})$ \\
\hline 4-carboxybenzenesulfonamide & 0.9 & $0.71(0.40)$ \\
\hline $\begin{array}{l}\text { 4-aminobenzenesulfonamide } \\
\text { (sulfanilic acid) }\end{array}$ & 10.3 & 8.20 \\
\hline GGHSLN & 6.5 & 5.20 \\
\hline Cu-GGHSLN & 6.3 & 5.00 \\
\hline
\end{tabular}

$\mathrm{K}_{\mathrm{M}}$ for substrate (4-nitrophenyl acetate) used to determine the parameters is $3.88 \mathrm{mM}$. Data in parenthesis is a reported $K_{D}$ value (Sigman et al. Biochemistry 1998, 37, 2096-2104). 